\title{
GRAMMAR OVERCOMING SOCIAL CONFLICT IN AXEL HONNETH'S THOUGHT
}

\author{
Ahmad Arrozy \\ Programmer for the Humanities Institute at research. \\ humaniora@gmail.com
}

\begin{abstract}
The thought of Axel Honneth (1995) is oriented towards recognition in tracing the grammar of social conflict. Each social group, which consists of professional, religious, or ethnic principles, has "own group language". Efforts to re-recognize the types of differences that cause social conflict are the initial mediation to track the position of rights and obligations so that those can be accepted in conflict resolution. The mode of recognition comes from an explorative study of Hegel's philosophical traditions. This article aims to dig deeper into the concept of conflict resolution. This study also focuses on how to watch the grammar of social conflict in order to find new mediation in dealing with social conflicts.
\end{abstract}

Keywords: social conflict, mediation, and recognition

\section{Introduction}

For post-reform, the discourse in the Indonesian public sphere encourages people to work with micro-businesses along with an infrastructure of internet and telecommunication network. This raises the attention of each cultural group in responding to more sensitive social-media conversations about the actualization of cyberspace business and political events.

If we make a reading of the incident that continued to be poured in the print media and the internet on the political conditions of Jakarta such as the statement of ex-Jakarta Governor Basuki Tjahaja Purnama or called as Ahok, mass democracy becomes a concept to be considered deliberately. Ahok's statement about Surah Al-Maidah: 51 led to large demonstrations among Muslims who were mostly as traders in urban areas. This matter becomes a factor of religious revival in Islam (Islamic revivalism). The merchant bases in the cities of Java and Sumatra have an educational infrastructure in the form of Islamic Studies Assembly in Mosques and Islamic Boarding Schools. Of course, every Assembly and Islamic Boarding School is led by a Hajj who is an ulama (religious figure). The movement is known as Aksi Bela Islam (Islamic Definition Action) on both 4 November and 2 December 2016 was a mass reaction from ulama actors to the statement of Governor Ahok who cited Surah Al-Maidah 51 outside the interpretation, even he was a follower of a non-Islamic religion or Christian (Koran Sindo, 2-12-2016). Beside 
this, at the level of industrialization, Chinese figures become the majority of the owners of companies and factories, either nationally and internationally.

There are many areas of Indonesia like Jababeka, Bekasi, and Subang that Chinese's people control as an industrial area, Sinarmas, Kino, and Indofood, for example. However, the majority of their workforce is Muslims. Of course, these suburbs of Jakarta had been able to pressure Ahok of his statement. The situation of suburbs made vis-a-vis between the Chinese power over the Indonesian economy and the majority of the mass base of Islam and its elites, whereas the law in Indonesia organized by the Government is carried out because of economic support between capital owners and politicians and military apparatus. In reality, there is no rule of the law or the principle of equality before the law. In recent years, Indonesia has only been projected as a marketplace for foreign investment networks and local capitalism, especially as evidenced by the re-election of Setya Novanto as Chair of the People's Election Council replacing Ade Komarrudin. With the existence of these positions, both sides manipulated public opinion with each other over the truth distortion that led to the peak of power.

If this evidence is drawn in terms of reading a conflictual model, it can be understood comprehensively as a majority conflict with a minority later because there is an unequal income between majority and minority. The revival of religion is an important thing considering that Muslims in Indonesia are the dominant group. On the other side, the position of "mass media" seemed to give a label to both parties. If protesting against the statement of Ahok it was considered as antidiversity and sectarian, while if studying the arguments and performance of Ahok it was also deemed as anti-Islamic. Ahok was also reminded several times by Islamic leaders to guard his oral before the events of October 6, 2016, which were about regulating the distribution of sacrificial animals and residents flat in Jakarta. However, Islamic people in Indonesia had been tired of listening to speeches considered rude about law enforcement, or unsuitable with cultural norms and procedures in Indonesia.

If the circumstance is drawn from the aspect of reading the study of democracy after reform it is a conflict between religious revival with Chinese entrepreneurs who generally control economic assets, especially in North Jakarta. Of course, Governor Ahok with a series of controversies was always covered by mass media such as the reclamation dispute and the Sumber Waras Hospital.

Jakarta as a trace of power centralism especially after the election of Joko Widodo as President has always been the arena of the mass media's attention, grassroots followers, party personnel, and political figures from both civilian and military. In the context of democracy in Indonesia, the influence of parties and public figures who have social 
networks and followers becomes a process of opposition such as Megawati Sukarno with Rachmawati Sukarno, Indonesian Democratic Party of Struggle (PDIP) with Golongan Karya (Golkar), and fellow retired military officers. Hence, every public figure has an idea of how to protect this country from the defense of the domestic economy in order to create an implementation of national welfare and social justice.

The social impact of the Governor Ahok's statement led to an unsympathetic reaction for Muslims because it was considered to deface the holy verse of Al-Maidah 51 . Automatically, this caused emotion from among Muslims so that even though there were political figures from Islamic circles who funded it, emotional factors became a predominant mass force of its own on how Muslims voluntarily left for Jakarta to hold demonstrations about the demands of law enforcement for Ahok.

The return of the "SARA Issue" (Tribe, Religion, Group, Race, and Group) is a retreat of the democracy's quality in Indonesia that should have reached the basis of performance and the distribution of justice. However, grassroots normativity in the form of a cultural group's grammar determines what groups and who are able to lead and organize an order on state performance to the aspirations of their people.

Clifford Geertz's observation of the political process in Indonesia generally originated from informal aspects in the form of collective awareness of each cultural group that gave rise to public issues. Geertz borrows a theoretical framework from Durkheim that collective awareness comes from the use of individual conscience ambiguities originating from cultural roots. Therefore, the political process in Indonesia, especially concerning critical decisions always comes from the public sphere where it becomes an instrument of grassroots democracy, and not from formal matters such as organizing parliament and presidium (Geertz, 1972). In the end, the crucial decision comes from the grassroots which press from the bottom up to the podium up.

The level of publicity that espouses democracy in Indonesia is the opposite line between the quality issues and the political stability of the state with cultural groups support it. The quality of a system concerns the fulfillment of individual rights and the formation of the government as a system of representation while the position of the government is the ability to maintain stability in institutional implementation (Nasikun, 1990). Academician of political science such as Arend Lijphart underlines the two positions, which are finally tested by the ability to overcome problems faced with all the ability to adapt to changing situations.

Axel Honneth looked at the study of the philosophy of socio-political morality, especially relations of power, recognition, and honor. One of the core arguments is for intersubjective priorities in the relationship 
of recognition in understanding social interaction. This step of thinking is free from misrecognition as the basis of social conflict and interpersonal aspects. Honneth gave an example of complaints about the distribution of goods in the society which eventually led to the struggle for recognition. The Honneth's main focuses on criticizing the concepts of power and reflective of the stages in socialcritical theory. He then explored the affinity between Frankfurt School and Michel Foucault.

"Language" as a product of cultural groups and their identities is the main source of socialization of individual morality and community ethics in order that it creates the grammatical moral concepts from social conflicts. The concept of "recognition" comes from G.W.F. Hegel with the social philosophy creativity, but supplemented by information from sociologist Herbert Mead with "symbolic interactionism", Juergen Habermas with "communicative actions", and Donald Winnicott in the object of social theory relations. Honneth made critical adaptations by changing the philosophy of critical social theory, which previously tried to correct the deficit approach in overcoming social conflict.

\section{Problems}

In 2003, did Honneth co-author the concept of recognition or redistribution with feminist philosopher Nancy Fraser?, They criticized categorical ethical priorities as acknowledging the category of socio-political structures in operational redistribution in the order of Honneth's thinking. His creativity on reification redefined the concept of "Western Marxism" in terms of intersubjectivity on the relationship of recognition and power allocation. For Honneth, all forms of reification are intersubjectivity aspects based on pathology rather than the structure and characterization of social systems such as capitalism as argued by Karl Marx and György Lukacs (Thompson, 2006). With a variety of cases and theoretical arguments, the sitting problem is as follows:

How the grammar overcome social conflicts in Axel Honneth's thought?

\section{Biography of Axel Honneth}

In a year full of political socialization, it would be good for Indonesian people how to comprehend the differences of opinion to keep away from prolonged political conflicts. Differences in opinion and political choice become a necessity for the course of human rights as political beings. The potential to be different sometimes results in interactive and collective conflicts in public spaces. Moreover, we need a process to ponder and recognize each other or referred to in the language of sociology as "recognition" to avoid social conflict.

The idea of recognition is the continuation of the public space sociology at the Social Institute in Frankfurt, Germany. This notion had been developed by Axel Honneth (1995) in his work The Struggle for 
Recognition: The Moral Grammar of Social Conflicts. In the tradition of humanitarian thought in Germany, Axel was indeed influenced by the philosopher Hegel, but it was just that Axel preferred to concentrate on the philosophy of civil society based on the results of sociological research.

Axel Honneth is a German philosophy graduate born in 1949. He studied in Bonn, Bochum, Berlin, and Munich (under the promotion of Jürgen Habermas), and taught freely at the University of Berlin and New School before moving to the University of Johann Wolfgang Goethe-Frankfurt in 1996. He also held the chair of Spinoza philosophy at the University of Amsterdam in 1999. In 2001, he became director of the Institute for Social Research, which was originally a Frankfurt School then held at the University of Frankfurt. Since 2011, Honneth worked together with humanities professor Jack Weinstein in the Department of Philosophy at Columbia City, New York City.

As the results of the study of psychologist Erich Fromm (1956), "self” condition between social relations is a shared desire that is equally desirable in a purpose. In relation to the actions and results of the achievement, "self" always gives for itself in the realization of action. Then there is the expansion of individual language into social languages because there are subjective desires as well as on topics of morality where identity characters occur in the public space and are predicted to experience conflicting attitudes. This is a reciprocal reaction to collective memory in which there is a process of knowing oneself to others or referred to as a society. True love for the process of sharing knowledge is only to point to the same relationship for knowing oneself on the other side. Hegel used the concept of morality recognition in the relationship of 'love' which is a process of recognition. Recognition in certain corridors is not always bad, because, in this way, the community is able to act honestly and rationally. This is also stated in the study of "subjectivity". Indeed, interpersonal skills are needed in social relations, so that in their actions they are able to provide space to introduce other people's perspectives on the available domains.

If subjective interests are collected, there is a form of reciprocal recognition in the choice of positive or negative domains. Of course, the hope of everyone in this political year is to choose positive reciprocity so that there is progress in growth. Then the prerequisites for achieving positive reciprocity are derived from a form of mutual recognition that is distinguished at the level of autonomy that has been done so far in different "division of roles". The mutual recognition is the material behind the existence of community law (metajuridical) which is an accommodative type. For example in practical political socialization, people needed to understand why there was a shift in professions such as parking lottery who worked as a successful team for political parties in local political narratives 
in Yogyakarta (Rifai, 2017). Perhaps it is necessary to appreciate recognition and acceptance because the economic situation made him involved in the political party's successful team. However, it does not mean that it is not critical in the realms of its actions considered wrong in the area of democracy which includes public space.

The argument above can be referred to as a subjective collection (intersubjective) expressed in public opinion so that opinion really determines the direction of the republic's institution. This comes from social relations that originate from the desire (ego) and the formed-social environment in order to produce superior perception in spurring self-awareness. The public opinion ultimately comes from the source of love for nationality in the family sphere (Galeotti, 2010). In other words, in the community sphere, it is a form of solidarity, whereas in public space it is a form of civil rights' fulfillment from all work attainments as an obligation.

Mutual recognition and mutual competition in goodness are a modern culture of how the form of community builds up mutually in the applications of constitutional and positive reciprocity. The way of thinking for recognition is based on "love relationships" that will pay attention to each other, especially to the interests of the community. With the act of "love" paying attention to each other, put themselves together, and understand each other's situation, everyone experiences an intuition reaction in the form of cooperation in the affective sphere. Recognition of the civil society's thinking way is able to provide a proportion of understanding where people actually are and in what scope. The process of getting to know each other is a collective effort regarding a "division of labor and expertise" so that this subject is a rational cooperation effort, and not only recognizes by ethnic or gender identity. This is the case in the urban and rural village communities in Indonesia.

\section{Theoretical Review}

In this study, Axel Honneth based the concept of recognition on Hegel's philosophical tradition becomes a variable in "civil society" in the disclosure of freedom and ethical responsibility (liberal art). Then the relationship between the state and the rights of individuals with the design of institutions are marked by dialectical developments. The concept of integralistic state refers to an organic unit and becomes a single goal. But in its development, integralistic states have received criticism from civil society advocacy because it is too totalitarian in the application of public policy. Even the application of public policy cannot be reckless in treating the status and role of "citizenship". However, public policy requires scientific evidence and social infrastructure.

The thought of Axel Honneth is an advanced program from sociologist Juergen Habermas at the Frankfurt Social Research Institute. The thought of communicative 
action is an attempt to overcome social conflict. This is expressed in Habermas's thought that social conflict comes from forms of coercion and manipulation (Collin and Pedersen, 2015). Habermas's thinking (1962) concluded that each group has a crucial period of moralistic decisions based on public interest. Habermas's discourse becomes a legacy in the development of cognition about the theory of public ethics based on the logic of rights and obligations.

Axel Honneth (1995) seeks to trace the dimensions of social conflict that lead to cultural relations with the structural transformation found by sociologist Juergen Habermas. "Language" is one of the means of connecting between two cultures with social structures. In each language, there is a grammar that operates in the realm of culture with a social structure that applies to every civil society. In the meeting, there are various types of community in the public sphere and should require public morality which is a grammar carrying out communication actions so that it is able to mediate social conflict (Habermas, 1990).

Honneth borrowed theconceptualization of "linguistic dysfunction" expressed by sociologist Lewis Coser. In the realm of conflict sociology, Coser stated that the existence of social conflict is a result of the machine language bureaucracy's dysfunctionality with the language of culture. Besides that, there is non-convergence of normative structures with existing structural patterns in the public sphere (Coser, 1957: 201). From this conception, it could be traced whether there are changes in rights and obligations in the historical period so that the quality of the atmosphere that creates fulfillment and equity is not achieved. The product for the grammar theory of social conflict based on the tracking of various injustice conditions comes from sociologist Baarington Moore (1978) who mentions the following aspects (Moore, 2015):

1. Description of individual personality that can be overcome through education.

2. The environment in the form of social structures and systems.

3. Unfinished national identity.

4. Legal-policy products that do not necessarily contain the principle of justice.

5. Different perceptions (knowledge systems) in different cultural spheres.

6. Territorial which is a source of economic mechanisms and assets.

7. Education of capital and capacity in achieving prosperity goals.

\section{Review}

The structure of Axel Honneth's thought in tracking the moral grammar of social conflict. Honneth stems from the tradition of G.W.F. Hegel's thought that in modern natural law, "human community" could only be conceptualized at the abstraction of the knowledge imagination united in a single 
subject (Honneth, 1995: 12). Then, there is the intersubjective pattern in the recognition process both actively and passively. Honneth tried to develop Hegel's thinking which gave intersubjectivity knowledge. For Hegel, there are two differentiations between positive legal language and what happens in the empirical and formal domains, (Honneth, 1995).

For example, the security forces gave a reason for the law in an incident commemorating the 10 November 2018 "Heroes' Day" in Surabaya which caused three people to die on the railroad bridge while watching the commemorative agenda (Kompas, 10-11-2018). In other words, the committee of the event conveyed to the Press that the pattern of watching the 10 November commemoration was like typical of watching football supporters spread throughout the arena that was not centered on one venue (Kompas Report, 10-11-2018). From this incident, it showed "language differences" between the language of the security apparatus based on the law and the language of the civil community in the form of a commemorative agenda committee which looked at the cultural norms of the local community. With the difference in language, if it is not carefully managed, it can lead to social conflict between the local security apparatus and the commemorative agenda committee as well as the families of the victims. The anticipation of dis-respect reactions with information and systems apply when the momentum of the process introduced social group identities.

Honneth traced the mode of Hegelian recognition originating from physicist Schelling who created a knowledge model that the text would disappear from the concept of subjectivity so as to get the effect of the differentiation of recognized groups and public figures. In tracking human history, the failed ethical life can raise questions from the status of violations and a social deviant. Hegel's argument about the process of legal formalization to support public ethics is given a constructive role for criminal acts.

Honneth experienced the difficulties in carrying out Hegel's philosophical relevance in the process of recognition because at this time the act of 'struggle' in the confession movement would be given negatively. Although there are challenges of transition functions also it is positive for those who respond functionally. All of this is aimed at "universalization" in each case so that the practical conditions can be digested to the next transition of social relations.

Hegel provided a theoretical conception that there is a social conflict based on the absence of reciprocity in various central roles. Applicable rules become a discourse of values that are proven to be collective goals. From synthesis, it requires roles that are able to explain the internal structure of a group that develops along with its relationships with other groups. The social philosophy model was developed by Hegel during a social conflict in the city of Jena (1804-1805). 
Table.1. The thought of Axel Honneth based on the Hegelians

\begin{tabular}{|c|c|c|c|}
\hline \multirow{2}{*}{$\begin{array}{l}\text { Mode of } \\
\text { Recognition }\end{array}$} & \multicolumn{3}{|c|}{ OBJECT OF RECOGNITION } \\
\hline & Individual Needs & Personal Autonomy & Individual Particularity \\
\hline $\begin{array}{l}\text { Intuition } \\
\text { (Affective) }\end{array}$ & \multicolumn{3}{|l|}{ Family (Love) } \\
\hline $\begin{array}{l}\text { Cognitive } \\
\text { Concept }\end{array}$ & \multicolumn{3}{|c|}{ Civil Society (Legal Prerequisites) } \\
\hline $\begin{array}{l}\text { Intuition } \\
\text { Intellectual } \\
\text { Rational }\end{array}$ & \multicolumn{3}{|c|}{ Solidarity of State Level (As State } \\
\hline
\end{tabular}

The Hegelian tradition begins the model from speculative theses that originate from self-formation and practically presuppose mutual recognition between various material negotiations. Not only does it stop at this level, but each individual can be confirmed to reach an understanding of themselves as selfindividuated actions. This thesis has become a point of departure because it reveals the basic structural features of the subject's community with those concerned in the theory of ethical agreement. But the mind that remains bound by pre-presuppositions comes from the metaphysical tradition because it bases the intersubjectivity relationship as an empirical event in the social mind of every human being. Hegel builds a formation between the intelligence of each individual to bring effort closer and things that are considered to be readjusted to society or in the terminology of social philosophy it is called "reappropriate" (Honneth, 1995).
Therefore, the second thesis (and the first constitutive of Hegel's conceptual model) is needed, asserting, based on local intersubjectivity. Those are supported by the existence various forms of mutual recognition and acceptability, which are distinguished according to their level of autonomy, are able to make the probability of accessing resolution to agents, whilst the ethical life system and the reality of social philosophy at least intersect with "love", "sense of belonging", and "recht". At this stage, Honneth expresses the need for the collective imagination of shared destinations. This imagery is part of renewing social construction with the support of phenomenology empirically. Then the thesis, antithesis, and synthesis are re-tested or reflected with the aim of improving practices considered to be a common goal. 
Table.2. Mode of Recognition for Axel Honneth's Thought

\begin{tabular}{|c|l|l|l|l|}
\hline $\mathbf{1}$ & Mode of Recognition & Emotional Support & $\begin{array}{l}\text { Cognition and } \\
\text { Respect }\end{array}$ & Social Reward \\
\hline $\mathbf{2}$ & Personal dimension & $\begin{array}{l}\text { Needs \& } \\
\text { Emotion }\end{array}$ & $\begin{array}{l}\text { Moral } \\
\text { Responsible }\end{array}$ & $\begin{array}{l}\text { Characteristic \& } \\
\text { Ability }\end{array}$ \\
\hline $\mathbf{3}$ & Form of Recognition & $\begin{array}{l}\text { Main Relationship: } \\
\text { Love and } \\
\text { Companion }\end{array}$ & $\begin{array}{l}\text { Distribution } \\
\text { Right }\end{array}$ & $\begin{array}{l}\text { Community Value } \\
\text { (Solidarity) }\end{array}$ \\
\hline $\mathbf{4}$ & $\begin{array}{l}\text { Potential } \\
\text { Development }\end{array}$ & -------- & $\begin{array}{l}\text { Generalization \& } \\
\text { Deformalization }\end{array}$ & $\begin{array}{l}\text { Individualization \& } \\
\text { Equalization }\end{array}$ \\
\hline $\mathbf{5}$ & Self-Relation Practice & $\begin{array}{l}\text { Basic of Self } \\
\text { Confidence }\end{array}$ & Self-Honor & Self-appreciation \\
\hline $\mathbf{6}$ & Form Dis-Respect & $\begin{array}{l}\text { Abuse \& } \\
\text { Harassment }\end{array}$ & Social Exclusion & $\begin{array}{l}\text { Slander, } \\
\text { Insult }\end{array}$ \\
\hline $\mathbf{7}$ & Personal Components & $\begin{array}{l}\text { Physical } \\
\text { Integration }\end{array}$ & Social Integration & Dignity Reward \\
\hline
\end{tabular}

Finally, the Hegel conceptual model has been completed at the destination stage. It is a thesis that follows a sequential form of formative logic processes' recognition that is connected by the stage of struggle for public morality. Public morality is a social convention of forming group identity towards community integration. In this case, it requires self-reflection on the transcendental deepening so that from the umpteenth time it can be decomposed intersubjectivity in social conflict, then the result lies in the recognition and social acceptance based on autonomy which previously did not assert social negation (Honneth, 1995).

There are two equally strong statements flowing into Hegel's thesis, which begin to appear only in the line of thought of Hegel in Jena that will be discussed below. First, the existence of individuals who have an ego in self-development is able to presume ongoing reciprocity. Second, with the recognition of the subject being informed by memories of nuanced experiences, that require involvement in efforts towards recognition. The second hypothesis is tied to the metaphysics of commitment to the framework of the theory on the development of religion (theology) which leads to the process of forming identity to the formation of social structures. For groups and actors who will try to re-appropriate efforts, Hegel's conceptualization model seeks to change the theoretical conditions of complex tangles to become a major challenge for actors that face speculative ways (Honneth, 1995: 69).

Differencesgenerallylead to the collective identity of a group or actor. In this case, the achievement modality is social capital that can be abstracted from the collective tendency of the status groups who are recipients of social awards. In practical terms, individual 
relationships run experience of recognition to achieve group pride or concerning the honor of a group (Galeotti, 2010). In this scope, individuals know themselves to be members of social groups that collectively achieve valuable things for being recognized in the societal domain. Internal relations in group structures are able to take over the character of solidarity as an interactive relationship. The concept of solidarity has been applied in historical writing primarily as a reaction to political oppression (Thompson, 2010).

In the history of politics, nuances of social conflict resulted in resolutions usually ending in treaties based on the number of conflict's victims (Organski, 1985). A treaty makes the authority of an actor to dominate practical purposes and ignore intersubjectivity considerations. In this case, Honneth has a collective memory on the case and biography of Adolf Hitler (1934-1945). For Honneth, the social conflict which leads to social identity actually only consumes the energy of community change, therefore its importance is for the forum of politicians or public policy makers, namely to produce methods of justice distribution.

In achieving the method of justice distribution, the data on the needs and works of each creative group are required to support actors and social groups as well as how to formulate best practices that apply in the field. From this main point, reciprocity operates on a technical and practical level. The component of recognition relates to the connection of human and cultural values, namely the sensitivity of actions from industrial values (types of a profession), articulation of art (artistic), circulation of symbols, folklore, humor, local philosophy, and religion. It has a connection to multiculturalism in achieving democracy in the space of local and global markets (Seymour, 2010).

\section{Conclusion}

Social conflicts generally occur due to justice distribution's congestion in the form of allocating the rights and obligations from citizenship status (citizenship). Changes in rights and obligations can change with the development of civilization from the interactions of different local communities with global media. "Social reality" that occurs at the local level is at least able to be accepted (acceptability) in open mind in an effort to recognize again, as long as this type of reality does not harm the existence of the local community. The next stage requires dialogue, resolution, and reciprocity so as to be able to anticipate potential social conflicts. Each social group, which consists of professional, religious and tribal principles, each has its own "language of the group", while the way to overcome social conflict is to return to "grammar of group" by mediating and touching cultural institutions. The grammar of group is the disclosure of knowledge systems, communal systems of thinking with the encouragement of "community emotions" along with the actors 
who apply in the field. This can be traced through modes of recognition in various human relations. Humanistically, Axel Honneth's thought seeks to remind that "how to treat" between humans is different from a machine system that is applied in the rules of industrial society. From this point of view, the academic community and groups of public policymakers need the knowledge to identify where the language of social conflict is.

\section{References}

Collin, Finn. Pedersen, D.B. 2015. “ The Frankfurt School Science and Technological Studies". Social Epistemology. 29 ( 1 ), 44-72.

Coser, Lewis. 1957. "Social Conflict and Theory of Social Change". The British Journal of Sociology . 8 ( 3 ), 197-207.

Habermas, Juergen. 1990. Moral Consciousness and Communicative Action. Translated Lenhardt and Nicholsen. Cambridge, Mass. MIT Press.

Honneth, Axel. 1995. The Struggle for Recognition: The Moral Grammar of Social Conflicts. Translated Joel Anderson. Cambridge, MA. The MIT Press.

Kompas. 2018. Penonton Drama Kolosal Surabaya Membara Tertabrak Kereta Api [ Liputan Kompas TV ]. Indonesia: Kompas Group.

Kompas, 2018. " Tragedi Acara Surabaya Membara, Polisi Pastikan 3 Korban Tewas dan Luka-luka “. www.regional. kompas.com, 10/11/2018, 08: 51 WIB.
KoranSindo, 2016. “Supermassa, Superdamai “. Harian Sindo, 2/12/2016.

Galeotti, Anna. 2010. “Respect as Recognition: Some Political Implications “. The Plural States of Recognition. Seymour ( ed ). London. Palgrave.

Geertz, Clifford. 1972. "Afterword: The Politics of Meaning”. Culture and Politics in Indonesia. Claire Holt ( ed ). Ithaca. Cornell University Press.

Levy, Jacob. 2010. “ Multicultural Manners ". The Plural States of Recognition. Seymour ( ed ). London. Palgrave.

Moore, Barrington. 2015. Injustice: The Social Bases of Obedience and Revolt. New York, NY. Routledge.

Nasikun, J. 1990. " Konteks Sosio-Kultural Pelaksanaan Demokrasi di Indonesia " Beberapa Aspek Pembangunan Orde Baru : Esai-Esai Fisipol Bulaksumur. Zaini Abar ( ed ). Solo. Ramadhani.

Organski, A.F.K. 1985. Tahap-Tahap Perkembangan Politik. Jakarta. Akademika Pressindo.

Rifai, Nor. 2017. “ Politik Uang Dalam Pemilihan Kepala Desa : Studi Kasus Desa Sinduadi, Sleman “. Skripsi. Yogyakarta. Universitas Gadjah Mada. Seymour, Michael, ed. 2010. The Plural States of Recognition. London. Palgrave MacMillan.

Thompson, Simon. 2006. The Political Theory of Recognition. Cambridge, UK. Polity Press.

Thompson, Simon. 2010. " Models of Democracy of the Politics of Recognition “. The Plural States of Recognition. Seymour ( ed ). London. Palgrave. 